\title{
COVID-19 Pandemic: Its Origin, Implications and Treatments
}

\author{
Peter K. Law \\ Cell Therapy Institute, Wuhan, China \\ Email:peter@celltherapy.com
}

How to cite this paper: Law, P.K. (2020) COVID-19 Pandemic: Its Origin, Implications and Treatments. Open Journal of Regenerative Medicine, 9, 43-64. https://doi.org/10.4236/ojrm.2020.92006

Received: April 8, 2020

Accepted: April 18, 2020

Published: April 21, 2020

Copyright $\odot 2020$ by author(s) and Scientific Research Publishing Inc. This work is licensed under the Creative Commons Attribution International License (CC BY 4.0).

http://creativecommons.org/licenses/by/4.0/

\begin{abstract}
This is a succinct and current review of pertinent literature to guide developing serum therapy as an emergent treatment to save human lives at times of natural or genetically engineered viral/bacterial pandemics. The origin of 2019-nCoV and implications of COVID-19 are discussed using direct quotes of published scientific literature to avoid misinterpretation on this very important event that has caused great loss of human lives and international social economy. It is the goal of this review to warn against and to correct international misunderstanding created by deliberate falsification of scientific documentations and events. This misunderstanding may lead to further destruction of life, economy, and political relations. People should not be blind-sighted when making life decisions.
\end{abstract}

\section{Keywords}

2019-nCoV, COVID-19, Serum Therapy, Pandemics, Epidemics, Convalescent Plasma, Coronavirus, Vaccine, Bacteria, Mutation, Biologic Warfare Weapons

\section{Introduction}

Scientists are passionate with their visions, taking pride in their work, credit in their inventions, and responsibility to human society, all for the betterment of mankind. It is in this context that I present this review with the hope that biological warfare will be banned, and that mankind will unite to combat natural pandemics like plague, diphtheria and malaria.

My generation of baby-boomers was blessed with social/economic prosperity and no world war, the number one killer of mankind. However, what we experienced with COVID-19, H1N1, SARS, H7N1, H7N9, MERS, AIDS and Ebola within the last 30 years were terrorizing events with destruction of life, economy, relationship, and communication, leaving shadows of anxiety, fear, mistrust and 
discrimination for significant years of our relatively short lives. COVID-19's involvement of the livelihood of 7.7 billion people in 211 countries with an estimate of over 250,000 deaths before it ends is the equivalence of destruction second only to a World War. If we do not take haste to manage this human catastrophe, life in a year will be beyond comprehension.

As human beings, we need to establish emergency protocols to save lives, and to quickly rebuild and sustain social harmony and world economy at times of sudden pathogenic attacks. With continual competition in development of biological warfare weapons, sudden outbreaks, either intentional or unintentional, will render certain countries less desirable to be inhabited, even for those who had been pre-vaccinated, believing that they might become immunotolerant of the viral antigens. We will miss beautiful cultures that we once enjoyed and cherished.

\section{Once There was Peace}

Paleontology recorded that simple lives such as viruses and bacteria were original inhabitants of Earth some 3.5 billion years ago. The first mammal appeared 200 million years ago, and the first dinosaur, about 50 million years before it [1]. These evolutionary ancestors of man (Homo Sapiens) had survived bacterial and viral pathogens for 250 million years. Through evolution, they developed a highly specific and potent immune surveillance system throughout their bodies, distributed through the blood circulatory system.

By the time human beings came to exist some 3 million years ago, our immune system had already evolved to reach and sustain an equilibrium with the natural faunas of bacteria and viruses, including those found in the 20-millionyear-old flying mammalian species of bats [2]. It was not until groups of American virologists and molecular geneticists succeeded in editing viral DNA/cDNA/ RNA/m-RNA sequence in late-1990's that the equilibrium was broken.

By 1998, a wide variety of viral delivery vehicles for genes had been tested including murine retroviruses, recombinant adenoviral vectors, adeno-associated virus, HSV, EBV, HIV vectors, and baculovirus. Fusogenic peptides in combination with liposomes, or polymers, were used to enhance the release of plasmid DNA from endosomes. There were techniques to exploit the HIV-1 virus to engineer vectors for gene transfer, the combining of viruses with polymers or cationic lipids to improve gene transfer, the attachment of nuclear localization signal peptides to oligonucleotides to direct them to nuclei, and the invention of molecular switch systems allowing genes to be turned on or off at will [3].

\section{Origin of COVID-19}

2019-nCoV genomics indicated that it was a recombinant virus of SARS-CoV and HIV origins. The two species of viruses had distinct and distance pedigrees, and because of the different space and time of their existence, their recombinant had never appeared in a natural setting [4]. Therefore, 2019-nCoV could not be a product of nature, but rather a product of human genetic engineering. 
To uncover the scientific origin of the 2019-nCoV, it is necessary to understand certain pertinent scientific reports of gene therapy. Gene therapy encompasses interventions that involve deliberate alteration of the genetic material of living cells to prevent or to treat diseases [5]. This FDA definition places two major technologies into the field of gene therapy:

1) Conducted in February and published in The Lancet on July 14, 1990 by my team, myoblast transfer therapy is the world's first human gene therapy and somatic cell therapy [6]. Through natural cell fusion, which is inherent in myogenesis and muscle regeneration, genetically normal myoblasts inserted their nuclei with full complements of normal genes into hereditary DMD dystrophic muscle cells to produce dystrophin, a structural protein that was not produced in DMD muscles due to the genetic defect. The transfer of genetic material and information occurred in vivo, with the myoblasts serving as the source and the vehicle of gene transfer.

Gina Kolata reported on the front page of the New York Times on Sunday June 3, 1990 that "Cell Transplant Found Effective in Muscle Disease: Muscular Dystrophy Patient Showed Strength Increase in First Human Test." William French Anderson [7], then the Director of Virology of the National Institutes of Health (NIH), said that if the finding was confirmed, "This would be a landmark." [8] Dr. Francis Collins, then a gene therapy researcher at the University of Michigan in Ann Arbor said the research "is a promising lead...." [8]. He recognized that, "there are some real possibilities here..." and both were right with the myoblast technology [9]. Peter Gorner reported on the front page of the Chicago Tribune on April 6, 1992 that "Tests confirm promise of genetic treatment for dystrophy."

2) Single gene transduction

In September 1990, Anderson transferred the adenosine deaminase (ADA) gene into the $\mathrm{T}$ cells of a 4-year-old girl with severe combined immunodeficiency (SCID) using a retroviral vector [10]. Although the integrated vector and ADA gene expression persisted, the subject had to take regular medication throughout the two years of gene treatment. The authors concluded that this single gene therapy was safe and effective to treating patients with this very rare form of disease [11]. On that basis, NIH's Anderson claimed to be the first person ever to succeed in gene therapy [12] and became widely acclaimed by Americans as the "Father of Gene Therapy" [11] [12].

Central to this technology is the use of viruses as vectors to deliver normal copies of the faulty or missing gene into a particular cell type of a patient, hoping that the therapeutic gene will be expressed to produce a structural or regulatory protein, thereby alleviating the disease symptom(s) [13] [14].

However, viral vector gene transfer technology has not saved as many lives as once expected, but has killed many as I foretold. The viral related death of Jesse Gelsinger and participants of other trials in 1999 [15] compelled the FDA to re-evaluate gene therapy regulations, thus setting back the development of all 
gene therapy programs including mine using no virus but human somatic cells called myoblasts. There were numerous deficiencies associated with the use of the single gene transduction technology [9]. Much of the hurdles that were 18 years ago [16] [17] remain unresolved today.

Grandstands over the Human Genome Project (HGP) [18]-[23] and somatic gene therapies [10] [11] [16] [24] [25] [26] in the last three decades fueled enthusiasm that most human diseases would eventually be cured with molecular medicine [27] [28]. In his position as the Director of the National Institutes of Health (NIH), and in his "Language of God" [23], Collins not only did not provide any genetic treatment for COVID-19, he presented "evidence of make- beliefs" and misled the world with the natural origin of 2019-nCoV [29].

Amidst all the "if s", "but's", "possibly", and "almost certainly", Collins recorded, "So, what is the natural origin of the novel coronavirus responsible for the COVID-19 pandemic? The researchers [30] don't yet have a precise answer." People in Collins' position were often put in ugly situations of having to give up their scientific aptitude and choosing, because of political pressure from their immediate employer, the US Congress. I was once at the receiving end, or rather, non-receiving end of such malice [31].

Collins continued, "Existing computer models predicted that the new coronavirus would not bind to angiotensin converting enzyme II (ACE2) as well as the SARS virus. However, to their surprise, the researchers found that the spike protein of the new coronavirus actually bound far better than computer predictions." After presenting two scenarios of circumstantial evidence of genomic modeling, Collins concluded, "Either way, this study leaves little room to refute a natural origin for COVID-19." [29]

Collins continued, "The researchers [30] went on to analyze genomic data related to the overall molecular structure, or backbone, of the new coronavirus. Their analysis showed that the backbone of the new coronavirus's genome most closely resembles that of a bat coronavirus discovered after the COVID-19 pandemic began. However, the region that binds ACE2 resembles a novel virus found in pangolins, a strange-looking animal sometimes called a scaly anteater. This provides additional evidence that the coronavirus that causes COVID-19 almost certainly originated in nature. If the new coronavirus had been manufactured in a lab, scientists most likely would have used the backbones of coronaviruses already known to cause serious diseases in humans."

Was Collins talking about biological weapon in this last sentence? What kind of scientists were Collins referring to who would intentionally cause serious diseases in humans? In his tax-payers' entrusted position of NIH Director, Collins cited a non-committal reference [30] and presented a deliberate falsification of published scientific literature of studies described below that were supported by at least three Institutes of $\mathrm{NIH}$, to mislead the world that COVID-19 originated from a natural course of viral evolution of the Hubei bats.

I hereby present below the direct, unequivocal evidence that $2019-\mathrm{nCoV}$ is a 
biological warfare weapon originally produced in the USA, and that COVID-19 is a pre-meditated event designed for the USA to consolidate and to sustain political and economic supremacy internationally.

In 2008, a group of SARS-like CoVs (SL-CoVs) isolated from horseshoe bats had their $\mathrm{N}$ terminus of the spike protein ( $\mathrm{S}$ ) combined with a human immunodeficiency virus (HIV)-based pseudovirus system, together with cell lines expressing the angiotensin-converting enzyme 2 (ACE2) molecules of human, civet, or horseshoe bat. Ren et al. reported, "in addition to full-length $\mathrm{S}$ of SL-CoV and SARS-CoV, a series of S chimeras was constructed by inserting different sequences of the SARS-CoV S into the SL-CoV S backbone."

This was a Guided Natural Selection, a process designed to select a lethal, transmissible virus by serially infecting cells of an animal model that had ACE2 receptors similar to human. The chimeric $S$ (spike) covering the receptor-binding domain (RBD) gained its ability to enter cells via human ACE2 receptor sites. The Chinese authors demonstrated that "after replacement of a small segment (aa 310 to 518) of Rp3-S by the cognate sequence of BJ01-S, the chimeric spike protein mimics the function of BJ01-S in regard to receptor usage in the HIV pseudovirus assay system." That was sufficient to convert the SL-CoV S from non-ACE2 binding to human ACE2 binding, indicating that the SL-CoV S is largely compatible with SARS-CoV S protein both in structure and in function [32]. The CoV spike glycoproteins were responsible for cellular receptor recognition [32] [33], cell tropism [34] [35], and host specificity [36].

Ren et al. also reported failure of SARS-CoV S protein to use bat RpACE2 as a receptor, suggesting that despite the presence of a diverse group of SL-CoVs in horseshoe bats, they were unlikely to be the natural reservoir of the immediate progenitor virus for SARS-CoV [32]. That was a non-committal way of saying that SARS-CoV did not have a natural origin.

Hou et al. (2010) [37] extended the above study to ACE2 molecules from seven additional bat species and tested their interactions with human SARS-CoV spike protein using both HIV-based pseudotype and live SARS-CoV infection assays. Live SARS-CoV infection was carried out with help from Gary Crameri and Jennifer Barr, under BioDefense Level 4 (BSL4) conditions at the Australian Animal Health Laboratory (AAHL) [38] [39]. The results, as reported by a group of Chinese scientists funded by the Chinese government, showed that "ACE2 of Myotis daubentoni and Rhinolophus sinicus from Hubei province supported viral entry mediated by the SARS-CoV S protein, albeit with different efficiency in comparison to that of the human ACE2." Further, "the alteration of several key residues either decreased or enhanced bat ACE2 receptor efficiency" [39].

How effective was this genetically engineered construct that was capable of transmission cross-species from bat to human, and within the same species from human to human? Gain of function (GOF) by which the efficiency of viral spreading in human population was engineered and tested in an international collaborative study in 2015 as reported by Menachery et al. Using the SARS-CoV 
reverse genetics system [40], a chimeric virus was generated and characterized expressing the spike of bat coronavirus SHC014 [41] in a mouse-adapted SARS-CoV backbone. The University of North Carolina (UNC) collaborative study indicated that viruses encoding the SHC014 spike in a wild-type backbone could efficiently use multiple orthologs of the SARS receptor human ACE2, replicate efficiently in primary human airway cells and achieve in vitro titers equivalent to epidemic strains of SARS-CoV.

Additionally, in vivo experiments demonstrated replication of the chimeric virus in mouse lung with notable pathogenesis [41]. Evaluation of available SARS-based immune-therapeutic and prophylactic modalities revealed poor efficacy; both monoclonal antibody and vaccine approaches failed to neutralize and protect from infection with CoVs using the novel spike protein. An infectious full-length SHC014 recombinant virus was synthetically re-derived and it demonstrated robust viral replication both in vitro and in vivo.

\section{Implications of COVID-19}

Menachery et al.'s 2015 [41] publication deserved every attention because it described the success of an international collaboration to genetically engineered a prototype of 2019-nCoV, confirmed its epidemic destructive capacity, demonstrated no effective medicament, vaccine, or any therapeutic or prophylactic modality, and predicted that COVID-19 would be preeminent. It described, "In addition to offering preparation against future emerging viruses, this approach must be considered in the context of the US government-mandated pause on gain-of-function (GOF) studies." A moratorium was called to end risky virology studies at 14 American institutions, but such effort was in vain [42].

Human ingenuity had advanced viral and bat evolution by a million years, providing them with the new ability to kill mankind. The combined use of virus recombination [32] [33], host switching [32] [33] [34] [35] and GOF [41] were achieved. SARS-coronavirus was known for its wide-spread efficiency in populating the upper respiratory tracks, and genuine HIV plasmid could devastate the infected individual's immune system; and in this case, the target of viral entry is ACE2 receptors of human beings. The combined use of the virus recombination technology and the host switching technology was already research in the wrong direction, upsetting the million-year-old natural equilibrium between human, bats and viruses. It was the GOF, a DNA engineering technology that propelled the efficiency of transmission among the human population of this monstrous chimaera (Figure 1) of SARS-CoV and HIV recombinant to the epidemic and pandemic level.

From the 1998 viral P-shuttle SN Vector to the present clustered regularly interspaced short palindromic repeats (CRISPR) gene editing technology, SHC014CoV, the prototype of 2019-nCoV, was the prime of viral genetic engineering, and a deadly one. It was biological weapon at its best. It was scientifically carried out with vision and passion, and the inventors given due credits in 


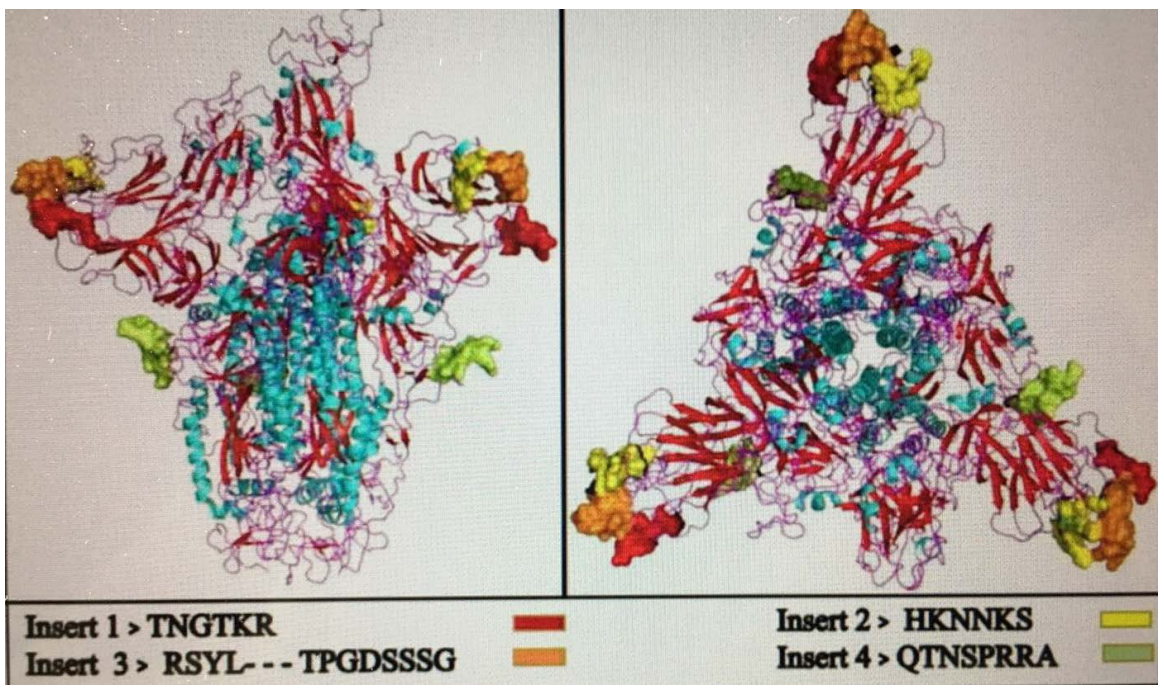

Figure 1. Modelled homo-trimer spike glycoprotein of 2019-nCoV. The inserts from HIV envelop protein are shown with colored beads, present at the binding site of the protein, from [47].

funding and publications for their inventions. However, this invention was to benefit no human beings or bats; it would kill them by the millions if left uncontrolled. It revolutionized military warfare, killing enemies without deploying troops, without demarcating boundary, without war declaration, and usually without knowledge or evidence of attack. This invention enabled its owner to kill any mammals having human ACE2 receptors.

The 2015 publication of Menachery et al. alerted a potential pandemic if uncurbed [41]. In the title of the original article published in Nature Medicine, it used the phrase of "pose threat to human emergence". That was five years before COVID-19, in the land of technologic totalism of USA, where two Chinese scientists shared their academic advances and were given the middle and the second-last placement in the long 15-author list. It was for the American technology of GOF that they collaborated with UNC. The latter was close to Fort Detrick, a key BioDefense Laboratory of the $4^{\text {th }}$ level (BSL4) for biologic weapon production and testing. The GOF "turbo-charged" the SARS-CoV/HIV recombinant and, for the first time, transformed it to become the world's most power biological weapon of pandemic caliber. This is the origin of the 2019-nCoV.

Author Contribution of Menarchery et al. recorded, "V.D.M. designed, coordinated and performed experiments, completed analysis and wrote the manuscript. B.L.Y. designed the infectious clone and recovered chimeric viruses.....R.S.B. designed experiments and wrote manuscript." These were the original responsible scientific designers of the biological bomb that left 1,852,021 diagnostically infected with COVID-19, and 114,090 dead in 211 countries on April 13, 2020, and these numbers are on an exponential up-swing.

As for "preparation against future emerging viruses" since Menarchery et als publication five years ago, only one publication has appeared six days ago on April 6, 2020 from the same UNC laboratory of Prof. Ralph S. Baric where 
2019-nCoV prototype was engineered and tested. It documented a vaccine which was tested on mice might be a potential treatment for COVID-19. Otherwise, there has been no documentation of any of the 2019-nCoV transmitting bats, if any, were killed to protect human lives. There has not been publication of studies documenting inoculation of bats with 2019-nCoV to study if bat-virus relationship is symbiotic or parasitic, and how well do the bats immune-tolerate these natural or foreign antigens.

To a business mind, why spent the money to make a man-killing chimeric virus, and found a vaccine against it, unless the vaccine could be sold at a good profit. However, it is extremely hard if not impossible to develop such vaccine, even by the UNC team itself [43]. Due to the tremendous random recombination of the chimeric viral RNA with different DNA repertoires from different patients by nature, no vaccine can be completely effective in principle, not even manufactured by Baric's team from UNC for Americans [43]. The only scientifically valid vaccine can only be derived from pooled antisera of rehabilitated patients of the same blood type [44] [45]. Immediately available therapy for the critically-ill and dying patients could only be from serum therapy as previously described [44] [45]. One's own immune system is the number one protection. Failing that, passive immunogens [44] [45] have to be implemented immediately to save lives.

The study of Menachery et al. was heavily funded. Its Acknowledgement cited, "Research in this manuscript was supported by grants from the National Institute of Allergy \& Infectious Disease and the National Institute of Aging of the US National Institutes of Health (NIH) under awards U19AI109761 (R.S.B.), U19AI107810 (R.S.B.), AI085524 (W.A.M.), F32AI102561 (V.D.M.) and K99AG049092 (V.D.M.), and by the National Natural Science Foundation of China awards 81290341 (Z.-L.S.) and 31470260 (X.-Y.G.), and by USAID-EPTPREDICT funding from EcoHealth Alliance (Z.-L.S.). Human airway epithelial cultures were supported by the National Institute of Diabetes and Digestive and Kidney Disease of the NIH under award NIH DK065988 (S.H.R.). We also thank M.T. Ferris (Dept. of Genetics, University of North Carolina) for the reviewing of statistical approaches and C.T. Tseng (Dept. of Microbiology and Immunology, University of Texas Medical Branch) for providing Calu-3 cells.”

A very unusual and unique statement appeared at the end of the Acknowledgement, "Experiments with the full-length and chimeric SHC014 recombinant viruses were initiated and performed before the GOF research funding pause and have since been reviewed and approved for continued study by the NIH. The content is solely the responsibility of the authors and does not necessarily represent the official views of the NIH." These last two sentences constituted a $\mathrm{NIH}$ disclaimer. What had the sponsors have in mind when they funded this project? No scientist would believe that the project was for the benefit of man, bat, or virus.

Coutarda et al. identified a furin-like cleavage site present in 2019-nCoV, SARS CoV and in MERS-CoV but absent in CoV of the same clade. "This furin- 
like cleavage site, was supposed to be cleaved during virus egress [46] for S-protein "priming" and might provide a gain-of-function (GOF) to the 2019-nCoV for efficient spreading in the human population compared to other lineage b betacoronaviruses".

"Strikingly, the 2019-nCoV S-protein sequence contains 12 additional nucleotides" [4]. These are the "insertions" of genetic engineering.

Prof. Francis Boyle of the University of Indiana who drafted the 1989 Biological Weapons Act considered Menachery et al.'s SHC014CoV or the 2019-nCoV as "an offensive biological warfare agent, and it has no legitimate scientific, or medical use of the Gain-of-Function (GOF) technology" [47]. It was Prof. Boyle's responsibility to oversee biologic warfare in the USA. According to Boyle, GOF was a DNA genetic engineering technology of "turbo-charging" dangerous biological warfare substances or pathogens. In the Alex Jones Show [47], he spoke of 12 warfare bases housing many BSL3/BSL4 laboratories specialized in system engineering of biological warfare weapons in the USA, and the BSL3/BSL4 warfare laboratories of Fort Detrick in Maryland was one of them. According to the news report, Fort Detrick had its license revoked last July after an outbreak similar to COVID-19, killing about 20,000 people with $75 \%$ of nearby citizens infected. He said he had condemned Fort Detrick and the UNC for violating the 1989 Biological Weapons Act that he drafted, for "turbo-charging" every pathogen including SARS-CoV and MERS- CoV that he proclaimed were bioweapons from Fort Detrick. He insisted that Fort Detrick should be shut down and their investigators be fully investigated.

In the name of academic pursuit and human health, various Institute Directors of NIH, beginning with French Anderson of the Institute of Virology unto the NIH Director Francis Collins, used American tax-payers' money to fund studies to manufacture and test viruses that no others bore a closer resemblance to $2019-\mathrm{nCoV}$, at least five years ago. For all that "preparation against future emerging viruses", NIH had not developed any safe and effective treatment. When concerned scientists called moratorium to end U.S. Government mandated pause on GOF projects, NIH Directors unloaded their responsibilities with a disclaimer and funded these man-killing projects with American tax-payers' money. Is this Liberty and Justice for All?

FDA scientist was an author in this man-killing project of Menachery et al. Crime against humanity had been FDA's specialty [48] [49] [50]. Inside the ivory tower of FDA inhabited many corruptive bureaucrats who would act or not act according to directions. After forcing me out of the USA as a foreign leading scientist holding key patents on myoblast transplantation technology, FDA has listed 23 projects in Phase II/III clinical trial, with more listed under muscle stem cells. EMA also listed 6 projects of myoblast transplantation. This latter platform technology had produced safe and effective therapies for muscular dystrophies, cardiomyopathies, Type-II diabetes, solid tumor and aging accounting for $80 \%$ of human death discounting war and pandemic deaths [51]. 
In December, 2019, USA refused to sign a new international protocol to ban biological warfare. USA has developed the best of biological warfare weapons and has set up 200 BioDefense laboratories around the world. USA has been the only country that refused WHO inspection of its biological warfare laboratories. When CDC suspended the BSL3/4 license from Fort Detrick last July, and demanded close-down of its facility and destruction of its records, many of its workers had already been contaminated, ending in COVID-19 outbreak in the East Coast cities. As of April 13, 2020, COVID-19 is on an exponential up-swing in USA, causing 22,090 deaths and 560,055 accumulatively diagnosed patients within the last four weeks. Vaccination had not been completely effective, especially for elderly patients with underlying illnesses.

It took some ruthless, law-unbinding, and power-hungry men who wanted to take lives of their fellow men to boost the political and economic supremacy of their own, less their country. They developed, owned, and used the products of the three jointly applied technologies described above. It took someone who was already rich and in power, who could convince the U.S. Congress to exert pressure onto NIH Director and Directors to fund this and previous man-killing projects, to the extent that NIH had to issue disclaimer statements for its own protection.

On March 17, 2020, U. S. President Donald Trump began to proclaime 2019-nCoV as "Chinese virus" on world news, to mislead the world and setting the pace for China to pay for COVID-19 world damages. Most people believed President Trump's version on international television; his telling of Chinese virus jumped onto human from eating bats in a broth. Those with higher intelligence preferred the more exotic bat sashimi, arguing that the 2019-nCoV could not have survived $86^{\circ} \mathrm{C}$, less boiling at $100^{\circ} \mathrm{C}$ in the broth.

On March 25, at the recommendation of President Trump, 54\% of the Republican and $36 \%$ of the Democratic members of the U.S. Congress voted to demand China to pay for at least part of the damages, with $42 \%$ of the American voters' support, $28 \%$ willing to go to war without hesitation if China refused to pay.

On March 29, American news announced that China was the first country to have COVID-19. The U. S. government had threatened not to repay all or portion of the U.S. debts borrowed from China, amounting to one thousand billion U.S. dollars, for punishing the Chinese government's delay in the control of COVID-19 spreading from bat-eating in the Hua Nan Seafood Market in Wuhan. Strangely enough, it had completely avoided talks of biological warfare, but insisted on condemnation news of Chinese viruses from Wuhan bats.

Recent poll announced that $68 \%$ of the American voters, mostly misled, was in support of this action. Without fully understanding the true origins of 2019-nCoV and COVID-19, many innocent Americans may be misled to go to war and die for a wrong cause. There is no reason for China to pay one thousand billion U.S. dollars to admit a crime which China did not commit. In the sixties 
of the last century, many young Americans took anti-war actions and refused to fight the Viet Nam War.

It is the goal of this review to warn against and to correct international misunderstanding created by deliberate falsification of scientific documentations and events. This misunderstanding may lead to war and further destruction of life, economy, and political relations. People should not be blind-sighted when making life decisions. It is my social responsibility, as a scientist, to inform the world of the scientific origins of 2019-nCoV and COVID-19. It is time for scientists to form alliance to speak up and to protect everything that belongs to human society. Left unchecked, COVID-19 will leave us with death, destruction, and grief, only second to the last world war.

Since December 12, 2019, 2019-nCoV has affected 211 countries and the livelihood of 7.7 billion people. As of April 13, 2020, 1,852,021 people have been diagnosed infected. COVID-19 has only been active for 4 months, and has already killed 114,090 people. If allowed to propagate, it could easily kill 250,000 people in a year.

COVID-19 was basically contained by March 18, 2020 in China with no new case reported until imported cases. It took a strong leadership, a great government, good directions of the medical experts, solidarity and discipline of the Chinese people, and sacrifice of the medical professionals all working together to achieve such a result. China has set examples of treatment and has helped different men of the world to fight our true enemy, the 2019-nCoV. Let us join hands doing just that.

There was no declaration of war, no gunfire or explosives. There was no country boundary to fight over. The enemy could not be seen. Human beings were fearful of the viral presence. It had taken away our freedom to travel, make friends, and explore opportunities of all sorts on the Belt Road and around the world. 2019-nCoV left husband and wife to become killing partners, and respectable elderly dead alone without attendance. So much time, efforts and resources spent on constructing the friendly world connection of Belt Road for mankind were wasted and the project de-railed.

Could we ever go back to the peaceful time that we once had when we could breathe the air of freedom, and enjoy the beauties around us? People of all races, colors, religions, ages, sexes, sizes have suffered, and will continue to suffer until we stop funding, designing, manufacturing, facilitating and using biological warfare weapons such as 2019-nCoV, H1N1, SARS, H7N1, H7N9, MERS, HIV and Ebola. These were pre-meditated, cold blood murders.

Long before the 2019 outbreak of COVD-19 in the USA, Coronavirus of Clades A, B, C, D, and E had already been in the records of American BSL3/BSL4 laboratories. The betacoronavirus of 2019-nCoV belongs to the $\mathrm{C}$ Clade. Despite all the bat species in Hubei, only the C Clade has been identified in China. There was no evidence of grand-parents (clade A), parents (clade B), children (clade D) or grand-children (clade E) of the 2019-CoV in China. This 
provided circumstantial evidence that COVID-19 in Wuhan might have derived from viruses overseas and not from China.

It is extraordinary that Britain, as one of the key entry ports into Europe, was relatively spared by COVID-19 as compared to Italy, the first country to sign-up with the Belt Road. It is extraordinary that Britain left the EU at the fortnight of COVD-19 outbreak in Europe, and its Prime Minister announced that British should not fear and could go on living as usual because they were healthy as if "immunized". This was similar to President Trump's announcement to the American public at the onset of COVID-19 in the USA. In North America, citizens received free annual Flu shots. Last fall, all 60-year-olds and above were given an extra "shot" against pneumonia.

\section{Treatment of COVID-19}

I had previously published the emergent serum therapy and antibody medicine to counteract sudden attacks of COVID-19 and other pathogenic epidemics [44] [45]. This is to provide background development leading to such.

\section{Regulatory and Compassionate Drug Usage}

Mono-antibodies produced against the primary structures of the viral DNA/RNA/mRNA demonstrated efficacy in viraemia reduction [52] [53], but clinical trials of CR3022 with CR3014 had never been tried due to the high cost of manufacturing [54] [55]. There were antiviral drugs designed to block viral replication. Ribavirin, lopinavir/ritonavir and corticosteroids had lowered 21-day ARDS and mortality than those who received ribavirin and corticosteroids together [56] [57].

Corticosteroids were not recommended by WHO [58] [59]. Corticosteroids caused local and systemic immunosuppression. Their administration had been associated with higher plasma viral load, slower viral clearance and higher mortality in both SARS and H1N1 [60]. Chloroquine was found to be a potent inhibitor of SARS coronavirus infection through interfering with ACE2, one of cell surface binding sites for S protein of SARS-CoV [61]. It would be useful in our combat against COVID-19, especially with early infection of mild cases. There were no clinical data on the efficacy of fusion inhibitors to prevent viral entry in SARS, MERS or COVID-19.

The diverse and potent neutralizing antibodies identified recently appeared to be promising candidates for prophylactic and therapeutic interventions for the 2019-nCoV [62]. The safety and efficacy of Remdesivir usage is doubtful for lack of statistics [63].

Without a compassionate use approval from the FDA/EMA/CFDA, drug discoveries had never been timely enough to gain regulatory approval to save lives, and may never will in a safe and efficacious manner.

\section{Evolutionary Antidote}

It is not only scientifically valid but also logical to deem convalescent serum therapy be the treatment of choice because the antiserum contains the antiviral 
antibodies IgG and IgG fragments that had won over the viral primary and mutated antigens to allow the patients to be rehabilitated [44] [45]. We do not have any other immunotherapy or medicament with virus-specific antibodies that works on the same mechanism and principle. Beating bacterial or viral infections can give "acquired immunity" where the immune system recognizes the infectious agent the next time it is encountered. This is done by antibodies that label or neutralize the infectious agent.

I could not have emphasized more that although the antiviral antibodies were contained in the lymph, serum, plasma and whole blood of the rehabilitated subject, transfusion of each component delivered different consequences for what each contained. A formal evaluation [44] [45] and a systematic review and exploratory meta-analysis [64] argued against the contention that the use of convalescent plasma as a treatment could be without the occurrence of severe adverse events [65]. Without properly-designed control studies, many patients who died of acute respiratory distress syndrome (ARDS) and/or multiple organ failure were counted as died of natural course of the diseases rather than serious adverse reactions triggered by non-scientific use of convalescent plasmas [66].

\section{Historic Development}

In Medieval times, death was often associated with blood loss, and blood transfusion for revitalizing wounded soldiers became a norm to save lives in the battle field. Without the knowledge of ABO-blood type matching, or how to control infections, most of these blood recipients died with few exceptions.

With the discovery of microscopy in 1665 , scientists could distinguish various cell types including the non-nucleated platelets. However, there were still question as to whether a dying man should have the whole blood of the donor, or the latter's plasma, or serum alone.

Serum therapies have been around since the late 1800's. In fact, the 1901 Nobel Prize was awarded to Emil von Behring for his pioneering work on them. Dr. von Behring is responsible for beating a diphtheria epidemic in Germany with the use of equine serum therapy. With the little equipment he had at the time, it was a tremendous triumph on his part for using ice to get clotted serum for his patients. Dr. von Behring opened up the field of immunology that has allowed scientists and physicians alike to understand pathogenesis and treatment of numerous diseases.

Discovery of ABO-blood typing was a very significant period during which mortality and morbidity were significantly reduced through blood transfusion. It is during this period that serum therapies became convalescent plasma therapies. It might be related to the rapid development of antibiotics and steroids. The latter development produced very lucrative profits that neither serum therapy nor convalescent plasma could match. Medical devices eventually were developed to provide plasma, especially platelet-rich-plasma (PRP), for battlefield usage in wound healing.

Convalescent Plasma against Epidemics 
COVID-19 refers to the outbreak of pneumonia pandemic induced by the severe acute respiratory syndrome coronavirus 2 (SARS-CoV-2), also known as 2019-nCoV. Convalescent plasma or immunoglobulins had been used as a last resort to improve the survival rate of patients with SARS whose condition continued to deteriorate despite treatment with pulsed methylprednisolone. Moreover, several studies showed a shorter hospital stay and lower mortality in patients treated with convalescent plasma than those who were not treated with convalescent plasma [66] [67] [68] [69]. In 2014, the use of convalescent plasma collected from patients who had recovered from Ebola virus disease was recommended by WHO as an empirical treatment during outbreaks [70] [71]. A protocol for the use of convalescent plasma in the treatment of Middle East respiratory syndrome coronavirus was established in 2015 [72] [73]. In terms of patients with pandemic 2009 influenza A H1N1 (H1N1pdm09) virus infection, a prospective cohort study by Hung and colleagues showed a significant reduction in the relative risk of mortality (odds ratio 0.20 [95\% CI $0.06-0.69$ ], $\mathrm{p}=0.01$ ) for patients treated with convalescent plasma [74]. Additionally, in a subgroup analysis, viral load after convalescent plasma treatment was significantly lower on days 3, 5, and 7 after intensive care unit admission. No adverse events were observed. A multi-center, prospective, double-blind, randomized controlled trial by Hung and colleagues showed that using convalescent plasma from patients who recovered from the influenza A H1N1pdm09 virus infection to treat patients with severe influenza A H1N1 infection was associated with a lower viral load and reduced mortality within 5 days of symptom onset [75].

Most of the treatment options for MERS were extrapolated from the 2003 outbreak of Severe Acute Respiratory Syndrome coronavirus (SARS-CoV) and the 2009 H1N1 influenza outbreak [76]. Like SARS-CoV, COVID-19 CoV binded to ACE-2 receptors and could also infect and replicate in macrophages, potentially leading to ARDS and death of the patients [66]. A meta-analysis by Mair-Jenkins and colleagues showed that the mortality was reduced in early-diagnosed patients with severe acute respiratory infections after receiving convalescent plasma, with no adverse events or complications after treatment [64].

Convalescent plasma is a form of passive immunotherapy. It was usually chosen when there were no specific vaccines or drugs available for emerging infection - related diseases [77] Arabi et al had tested the feasibility of convalescent plasma therapy as well as its safety and clinical efficacy in critically-ill MERS patients. They found that convalescent plasma had an immunotherapeutic potential for the treatment of MERS-CoV infection [72]. In addition, convalescent plasma from recovered SARS patients had also been reported to be useful clinically for treating other SARS patients [68] [69]. The use of convalescent plasma or serum was suggested by the WHO under Blood Regulators Network when vaccines and antiviral drugs were unavailable for an emerging virus. Convalescent plasma has been routinely used for the treatment of COVID-19 infected critically-ill patients in China [78]. 
Even as of today, biopharmaceutics and scientists continued making the same mistakes by using convalescent plasma without applying the precision technology of antigen-antibody specificity of convalescent serum therapy [79]. Some are repeating what they were taught; others refer to plasma and serum as if they are the same [79]. Very few are aware of the difference that they have caused between death or life for the critically-ill or dying patients. Although WHO recommended convalescent plasma to be used as an empirical treatment for Ebola in 2014 [71], it has not recommended the same for COVID-19 because of lack of evidence of safety and efficacy as of April 13, 2020, 2020 [59].

\section{Convalescent Serum against Pandemics}

Let us revisit the ingenuity of Emil Adolph von Behring, the Father of Immunology. During the poliomyelitis epidemic in 1917, Amoss and Chesney demonstrated that convalescent serum, when injected both intra-spinally and intravenously, significantly reduced paralysis, mortality rate, symptom severity, and hospital stay of critically-ill patients [80]. The earlier in the course of the disease the serum was employed in suitable doses, the more promise there was of benefit. The decision to employ the serum should rest upon a clinical examination supported by the results of the microscopic and chemical study of the cerebrospinal fluid. Reinjection 12 to 24 hours later may be advantageous; the temperature curve served to indicate the time for reinjection.

Meta-analysis by Luke and colleagues identified eight studies involving 1703 patients with 1918 influenza pneumonia from 1918 to 1925 who received an infusion of influenza-convalescent human blood products, which showed a pooled absolute reduction of $21 \%(95 \%$ CI $15-27 ; p<0.001)$ in the overall crude case fatality rate at low risk of bias [81].

The use of convalescent human serum in treating 37 influenza pneumonia patients in 1918 demonstrated that thirty were rehabilitated; six were continuing treatment; one had died; all but one of these had a favorable outlook [82]. Blood to the amount of about $800 \mathrm{cc}$. was taken from each donor, under sterile precautions; $400 \mathrm{cc}$. at a time on two successive days. Thus, each donor yielded about $300 \mathrm{cc}$. of serum. The blood was allowed to clot at room temperature for about an hour, then plate cultures were made, and the containers placed on ice. over night. The separated serum was cleared by centrifugalizing at high speed; then bottled, and in most cases given the same day.

Attempt was made to test the potency of the serum of the donors in the old days by complement fixation and by gross agglutination, using isolated influenza bacillus as an antigen. However, without PCR technology to assess the antibody content of the serum, efficacy can only be determined by its clinical action on recipients [83].

Serum therapies were successfully used to treat many infectious diseases (anthrax, plague, scarlet fever, measles, tularemia, diphtheria, dysentery, meningococcal meningitis, rabies, pneumococcal pneumonia) for half a century after Dr. Emil von Behring first demonstrated their effective use as a therapeutic in 
diphtheria. Their general use fell into disfavor after the advent of antibiotic therapies and in consideration of the problems of adverse reactions to animal derived sera and whole serum. However, human and animal derived immunoglobulins remain important therapies for a variety of conditions (parvovirus, CMV, hepatitis B, rabies, hepatitis A, botulism, envenoming, etc.)

The WHO deemed convalescent plasma as the most promising near-term therapy for MERS in the WHO-International Severe Acute Respiratory and Emerging Infection Consortium MERS-CoV Outbreak Readiness Workshop 2013 [83]. However, due to the lack of clinical trials, a WHO position paper published in March 2014 stated that the clinical use of convalescent plasma should be regarded as investigation WHO had issued a Position Paper on the collection and use of convalescent plasma or serum in emergent experimental therapies to treat MERS. This should be followed as guidelines to treating COVID-19.

\section{From Here to Recovery}

What do we do to prevent life from here to eternality?

1) Stop depositing biological bombs. Over a hundred thousand people have already been killed by $2019-\mathrm{nCoV}$.

2) Stop any scientific development toward biological warfare, especially funding. Set up surveillance systems to destroy and ban biological warfare weapons.

3) Implement serum therapy and research for vaccine in the correct way [44] [45] with haste and precision. Everyday counts; watch the death toll board.

4) Focus on and fund biomedical research and development. There will be no quality of life if we acquire fatal and debilitating diseases, and nothing matters if we are dead. Dead by 2019-nCoV is extremely painful.

\section{Conclusion}

These are COVID-19's treatment, origin and implications; the good, the bad, and the ugly. Gina Kolata or others may use this platform for me to discuss gene therapies with William French Anderson and Francis Collins 30 years after we created and established this very important field of biomedicine.

\section{Acknowledgements}

P. K. L. is a National Distinguished Expert of CHINA. This work was supported by the Cell Therapy Institute, Wuhan.

\section{Conflicts of Interest}

The author declares no conflicts of interest regarding the publication of this paper.

\section{References}

[1] Sherwood Romer, A. (1945) Vertebrate Paleontology. University of Chicago Press, 
Chicago, IL, 687 p.

[2] Hand, S.J., et al. (2009) Bats that Walk: A New Evolutionary Hypothesis for the Terrestrial Behaviour of New Zealand's Endemic Mystacinids. BMC Evolutionary Biology, 9, 169. https://doi.org/10.1186/1471-2148-9-169

[3] Boulikas, T. (1998) Status of Gene Therapy in 1997: Molecular Mechanisms, Disease Targets, and Clinical Applications. Gene Therapy \& Molecular Biology, 1, 1-172.

[4] Coutarda, B., Valleb, C., de Lamballeriea, X., Canardb, B., Seidahc, N.G. and Decroly, E. (2020) The Spike Glycoprotein of the New Coronavirus 2019-nCoV Contains a Furinlike Cleavage Site Absent in $\mathrm{CoV}$ of the Same Clade. Antiviral Research, 176, Article ID: 104742. https://doi.org/10.1016/j.antiviral.2020.104742

[5] Kessler, D.A., Siegel, J.P., Noguchi, P.D., Zoon, K.C., Feiden, K.L. and Woodcock, J. (1993) Regulation of Somatic Cell-Therapy and Gene Therapy by the Food and Drug Administration. The New England Journal of Medicine, 329, 1169-1173. https://doi.org/10.1056/NEJM199310143291607

[6] Law, P.K., Bertorini, T., Goodwin, T.G., Chen, M., Fang, Q.W., Li, H.J., et al. (1990) Dystrophin Production Induced by Myoblast Transfer Therapy in Duchenne Muscular Dystrophy. The Lancet, 336, 114-115.

https://doi.org/10.1016/0140-6736(90)91628-N

[7] Wikipedia (2013) William French Anderson. https://en.wikipedia.org/wiki/William_French_Anderson

[8] Kolata, G. (1990) Cell Transplant Found Effective in Muscle Disease: Muscular Dystrophy Patient Showed Strength Increase in First Test. New York Times.

[9] Law, P.K. (2016) Disease Prevention and Alleviation by Human Myoblast Transplantation. Open Journal of Regenerative Medicine, 5, 25-43. https://doi.org/10.4236/ojrm.2016.52003

[10] Anderson, W.F. (1990) Editorial. The Beginning. Human Gene Therapy, 1, 371-372. https://doi.org/10.1089/hum.1990.1.4-371

[11] Anderson, W.F. (1992) Human Gene Therapy. Science, 256, 808-813. https://doi.org/10.1126/science.1589762

[12] Anderson, W.F. (1995) Gene Therapy. Scientific American, 273, 96.

[13] Crystal, R.G. (1997) Transfer of Genes to Humans: Early Lesions and Obstacles to Success. Science, 270, 404-410. https://doi.org/10.1126/science.270.5235.404

[14] Verma, I. and Somia, N. (1997) Gene Therapy-Promises, Problems and Prospects. Nature, 389, 239-242. https://doi.org/10.1038/38410

[15] Thomas, C.E., Ehrhardt, A. and Kay, M.A. (2003) Progress and Problems with the Use of Viral Vectors for Gene Therapy. Nature Reviews Genetics, 4, 346-358. https://doi.org/10.1038/nrg1066

[16] Culver, K.W. (1996) The First Human Gene Therapy Experiment. In: Culver, K.W., Ed., Gene Therapy: A Primer for Physicians, Mary Ann Liebert, Inc., New York, 47-53.

[17] Brenner, M.K. (1995) Human Somatic Gene Therapy: Progress and Problems. Journal of Internal Medicine, 237, 229-239. https://doi.org/10.1111/j.1365-2796.1995.tb01171.x

[18] DeLisi, C. (1988) The Human Genome Project. American Scientist, 76, 488-493.

[19] Venter, J.C., Adams, M.D., Myers, E.W., Li, P.W., Mural, R.J., Sutton, G.G., et al. (2001) The Sequence of the Human Genome. Science, 291, 1304-1351. https://doi.org/10.1126/science.1058040 
[20] Venter, D. (2003) A Part of the Human Genome Sequence. Science, 299, 1183-1184. https://doi.org/10.1126/science.299.5610.1183

[21] White House Press Release. Retrieved on 22 July 2006.

[22] DeLisi, C. (2008) Meetings that Changed the World: Santa Fe 1986: Human Genome Baby-Steps. Nature, 455, 876- 877. https://doi.org/10.1038/455876a

[23] Collins, F. (2006) The Language of God: A Scientist Presents Evidence for Belief. Free Press, New York.

[24] Beardsley, T. (1990) Profile: Gene Doctor. W. French Anderson Pioneers Gene Therapy. Scientific American, 263, 33. https://doi.org/10.1038/scientificamerican0890-33

[25] Culver, K.W., Osborne, W.R., Miller, A.D., Fleisher, T.A., Berger, M., Anderson, W.F., et al. (1991) Correction of ADA Deficiency in Human T Lymphocytes Using Retroviral-Mediated Gene Transfer. Transplantation Proceedings, 23, 170-171.

[26] Karlsson, S. (1991) Treatment of Genetic Defects in Hematopoietic Cell Function by Gene Transfer. Blood, 78, 2481-2492. https://doi.org/10.1182/blood.V78.10.2481.2481

[27] Gonzaga-Jauregui, C., Lupski, J.R. and Gibbs, R.A. (2012) Human Genome Sequencing in Health and Disease. Annual Review of Medicine, 63, 35-61. https://doi.org/10.1146/annurev-med-051010-162644

[28] Snyder, M., Du, J. and Gerstein, M. (2012) Personal Genome Sequencing: Current Approaches and Challenges. Genes \& Development, 24, 423-431. https://doi.org/10.1101/gad.1864110

[29] Collins, F. (2020) Genomic Study Points to Natural Origin of COVID-19. NIH Director's Blog.

[30] Andersen, K.G., Rambaut, A., Lipkin, W.I., Holmes, E.C. and Garry, R.F. (2020) The Proximal Origin of SARS-CoV-2. Nature Medicine, 17. https://doi.org/10.1038/s41591-020-0820-9

[31] Law, P.K. (1992) Myoblast Transplantation. Science, 257, 1329-1330. https://doi.org/10.1126/science.1529326

[32] Ren, W., Qu, X., Li, W., Han, Z., Yu, M., Zhou, P., Zhang, S.Y., Wang, L.F., Deng, H. and Shi, Z (2008) Difference in Receptor Usage between Severe Acute Respiratory Syndrome (SARS) Coronavirus and SARS-Like Coronavirus of Bat Origin. Journal of Virology, 82, 1899-1907. https://doi.org/10.1128/JVI.01085-07

[33] Kuo, L., Godeke, G.J., Raamsman, M.J., Masters, P.S. and Rottier, P.J. (2000) Retargeting of Coronavirus by Substitution of the Spike Glycoprotein Ectodomain: Crossing the Host Cell Species Barrier. Journal of Virology, 74, 1393-1406. https://doi.org/10.1128/JVI.74.3.1393-1406.2000

[34] Casais, R., Dove, B. Cavanagh, D. and Britton, P. (2003) Recombinant Avian Infectious Bronchitis Virus Expressing a Heterologous Spike Gene Demonstrates that the Spike Protein Is a Determinant of Cell Tropism. Journal of Virology, 77, 9084-9089. https://doi.org/10.1128/JVI.77.16.9084-9089.2003

[35] Haijema, B.J., Volders, H. and Rottier, P.J. (2003) Switching Species Tropism: An Effective Way to Manipulate the Feline Coronavirus Genome. Journal of Virology, 77, 4528-4538. https://doi.org/10.1128/JVI.77.8.4528-4538.2003

[36] de Haan, C.A., Kuo, L., Masters, P.S., Vennema, H. and Rottier, P.J. (1998) Coronavirus Particle Assembly: Primary Structure Requirements of the Membrane Protein. Journal of Virology, 72, 6838-6850. https://doi.org/10.1128/JVI.72.8.6838-6850.1998 
[37] Hou, Y., Peng, C., Yu, M., Li, Y., Han, Z., Li, F., Wang, L.-F. and Shi, Z. (2020) Angiotensin-Converting Enzyme 2 (ACE2) Proteins of Different Bat Species Confer Variable Susceptibility to SARS-CoV Entry. Archives of Virology, 155, 1563-1569. https://doi.org/10.1007/s00705-010-0729-6

[38] Yu, M., Stevens, V., Berry, J.D., Crameri, G., McEachern, J., Tu, C., Shi, Z., Liang, G., Weingart, H., Cardosa, J., Eaton, B.T., Wang, L.F. (2008) Determination and Application of Immunodominant Regions of SARS Coronavirus Spike and Nucleocapsid Proteins Recognized by Sera from Different Animal Species. Journal of Immunological Methods, 331, 1-12. https://doi.org/10.1016/j.jim.2007.11.009

[39] Tu, C., Crameri, G., Kong, X., Chen, J., Sun, Y., Yu, M., Xiang, H., Xia, X., Liu, S., Ren, T., Yu, Y., Eaton, B.T., Xuan, H. and Wang, L.F. (2004) Antibodies to SARS Coronavirus in Civets. Emerging Infectious Diseases Journal, 10, 2244-2248. https://doi.org/10.3201/eid1012.040520

[40] Yount, B., et al. (2003) Reverse Genetics with a Full-Length Infectious cDNA of Severe Acute Respiratory Syndrome Coronavirus. Proceedings of the National Academy of Sciences of the United States of America, 100, 12995-13000. https://doi.org/10.1073/pnas.1735582100

[41] Menachery, V.D., Yount Jr., B.L., Debbink, K., Agnihothram, S., Gralinski, L.E., Plante, J.A., Graham, R.L., Scobey, T., Ge, X.-Y., Donaldson, E.F., Randell, S.H., Lanzavecchia, A., Marasco, W.A., Shi, Z.-L. and Baric, R.S. (2015) A SARS-Like Cluster of Circulating Bat Coronaviruses Shows Potential for Human Emergence. Nature Medicine, 21, 1508-1513. https://doi.org/10.1038/nm.3985

[42] Kaiser, J. (2014) Moratorium on Risky Virology Studies Leaves Work at 14 Institutions in Limbo. ScienceInsider.

http://news.sciencemag.org/biology/2014/11/moratoriumrisky-virology-studies-leav es-work-14-institutions-limbo

[43] Sheahan, T.P., Sims, A.C., Zho, S., Graham, R.L., Pruijssers, A.J., Agostini, M.L., et al. (2020) An Orally Bioavailable Broad-Spectrum Antiviral Inhibits SARS-CoV-2 in Human Airway Epithelial Cell Cultures and Multiple Coronaviruses in Mice. Science Translational Medicine. https://doi.org/10.1126/scitranslmed.abb5883

[44] Law, P.K. (2020) Emergent Serum Therapy and Antibody Medicine to Counteract Sudden Attacks of COVID-19 and Other Pathogenic Epidemics. Open Journal of Regenerative Medicine, 9, 1-7. https://www.scirp.org/journal/ojrm https://doi.org/10.4236/ojrm.2020.91001

[45] Law, P.K. (2020) System Engineering of Emergent Serum Therapy to Combat COVID-19 and Other Pathogenic Pandemics Open Journal of Regenerative Medicine, 9, 8-14. https://doi.org/10.4236/ojrm.2020.91002

[46] Millet, J.K. and Whittaker, G.R. (2014) Host Cell Entry of Middle East Respiratory Syndrome Coronavirus after Two-Step, Furin-Mediated Activation of the Spike Protein. Proceedings of the National Academy of Sciences of the United States of America, 111, 15214-15219. https://doi.org/10.1073/pnas.1407087111

[47] https://www.infowars.com/full-transcript-of-smoking-gun-bombshell-interview-pr of-francis-boyle-exposes-the-bioweapons-origin-of-the-covid-19-corona-virus

[48] Law, P.K. (2017) Crime against Humanity. Open Journal of Regenerative Medicine, 6, 35-45. https://doi.org/10.4236/ojrm.2017.64004

[49] Stennes, M.L. (1997) The Criminalization of Innovation: FDA Misdirection in the Najarian and Burzynski Cases (1997 Third Year Paper). Harvard Law School. http://nrs.harvard.edu/urn-3:HUL.InstRepos:9453691

[50] Seife, C. (2016) FDA Documents Reveal Depths of Internal Rancor over Drug's Ap- 
proval Process. Undark. https://undark.org/article/fda-eteplirsen-janet-woodcock/

[51] Law, P.K., et al (2019) Myoblasts Provide Safe and Effective Treatments for Hereditary Muscular Dystrophies, Cardiomyopathies, Type 2 Diabetes, Solid Tumors and Aging. In: Haider, K.H. and Aziz, S., Eds., Stem Cells-From Hype to Real Hope, Walter de Gruyter GmbH, Berlin, 71-97. https://doi.org/10.1515/9783110587043-004

[52] Schoofs, T., Klein, F., Braunschweig, M., et al. (2016) HIV-1 Therapy with Monoclonal Antibody 3BNC117 Elicits Host Immune Responses against HIV-1. Science, 352, 997-1001. https://doi.org/10.1126/science.aaf0972

[53] Lu, C.L., Murakowski, D.K., Bournazos, S., et al. (2016) Enhanced Clearance of HIV-1-Infected Cells by Broadly Neutralizing Antibodies against HIV-1 in Vivo. Science, 352, 1001-1004. https://doi.org/10.1126/science.aaf1279

[54] ter Meulen, J., van den Brink, E.N., Poon, L.L.M., et al. (2006) Human Monoclonal Antibody Combination against SARS Coronavirus: Synergy and Coverage of Escape Mutants. PLoS Medicine, 3, e237. https://doi.org/10.1371/journal.pmed.0030237

[55] ter Meulen, J., Bakker, A.B., van den Brink, E.N., et al. (2004) Human Monoclonal Antibody as Prophylaxis for SARS Coronavirus Infection in Ferrets. The Lancet, 363, 2139-2141. https://doi.org/10.1016/S0140-6736(04)16506-9

[56] Chu, C., Cheng, V., Hung, I., et al. (2004) Role of Lopinavir/Ritonavir in the Treatment of SARS: Initial Virological and Clinical Findings. Thorax, 59, 252-256. https://doi.org/10.1136/thorax.2003.012658

[57] Chan, K.S., Lai, S.T., Chu, C.M. et al. (2003) Treatment of Severe Acute Respiratory Syndrome with Lopinavir/Ritonavir: A Multicentre Retrospective Matched Cohort Study. Hong Kong Medical Journal, 9, 399-406.

[58] Clark, D.R., Jonathan, E.M., et al. (2020) Clinical Evidence Does Not Support Corticosteroid Treatment for 2019-nCoV Lung Injury. The Lancet.

[59] WHO (2020) Clinical Management of Severe Acute Respiratory Infection When Novel Coronavirus (nCoV) Infection Is Suspected.

https://www.who.int/docs/default-source/coronaviruse/clinical-management-of-no vel-cov.pdf

[60] Lee, N., Chan, A., Hui, K.C., et al. (2004) Effects of Early Corticosteroid Treatment on Plasma SARS-Associated Coronavirus RNA Concentrations in Adult Patients. Journal of Clinical Virology, 31, 304-309. https://doi.org/10.1016/j.jcv.2004.07.006

[61] Vincent, M.J., Bergeron, E., Benjannet, S., et al. (2005) Chloroquine Is a Potent Inhibitor of SARS Coronavirus Infection and Spread. Virology Journal, 2, 69. https://doi.org/10.1186/1743-422X-2-69

[62] Bin, J., Qi, Z., Ge, X., Wang, R., Yu, J., Shan, S., et al. (2020) Potent Human Neutralizing Antibodies Elicited by SARS-CoV-2 Infection. BioRxiv Preprint.

[63] Holshue, M.L., DeBolt, C., Lindquist, S., et al. (2020) First Case of 2019 Novel Coronavirus in the United States. The New England Journal of Medicine, 382 , 929-936. https://doi.org/10.1056/NEJMoa2001191

[64] Mair-Jenkins, J., Saavedra-Campos, M., Baillie, J.K., et al. (2015) The Effectiveness of Convalescent Plasma and Hyperimmune Immunoglobulin for the Treatment of Severe Acute Respiratory Infections of Viral Etiology: A Systematic Review and Exploratory Meta-Analysis. The Journal of Infectious Diseases, 211, 80-90. https://doi.org/10.1093/infdis/jiu396

[65] Chen, L., Xiong, J., Bao, L. and Shi, Y. (2020) Convalescent Plasma as a Potential Therapy for COVID-19. The Lancet Infectious Diseases. 
https://doi.org/10.1016/S1473-3099(20)30141-9

[66] Zhou, J., Chu, H., Li, C., et al. (2014) Active Replication of Middle East Respiratory Syndrome Coronavirus and Aberrant Induction of Inflammatory Cytokines and Chemokines in Human Macrophages: Implications for Pathogenesis. The Journal of Infectious Diseases, 209, 1331-1342. https://doi.org/10.1093/infdis/jit504

[67] Lai, S.T. (2005) Treatment of Severe Acute Respiratory Syndrome. European Journal of Clinical Microbiology \& Infectious Diseases, 24, 583-591. https://doi.org/10.1007/s10096-005-0004-Z

[68] Soo, Y.O., Cheng, Y., Wong, R., et al. (2004) Retrospective Comparison of Convalescent Plasma with Continuing High-Dose Methylprednisolone Treatment in SARS Patients. Clinical Microbiology and Infection, 10, 676-678. https://doi.org/10.1111/j.1469-0691.2004.00956.x

[69] Cheng, Y., Wong, R., Soo, Y.O., et al. (2005) Use of Convalescent Plasma Therapy in SARS Patients in Hong Kong. European Journal of Clinical Microbiology \& Infectious Diseases, 24, 44-46. https://doi.org/10.1007/s10096-004-1271-9

[70] Chippaux, J.-P., Boyer, L.V. and Alagón, A. (2015) Post-Exposure Treatment of Ebola Virus Using Passive Immunotherapy: Proposal for a New Strategy. Journal of Venomous Animals and Toxins including Tropical Diseases, 21, 3. https://doi.org/10.1186/s40409-015-0003-1

[71] WHO (2020) Use of Convalescent Whole Blood or Plasma Collected from Patients Recovered from Ebola Virus Disease for Transfusion, as an Empirical Treatment during Outbreaks. http://apps.who.int/iris/rest/bitstreams/604045/retrieve

[72] Arabi, Y., Balkhy, H. and Hajeer, A.H. (2015) Feasibility, Safety, Clinical, and Laboratory Effects of Convalescent Plasma Therapy for Patients with Middle East Respiratory Syndrome Coronavirus Infection: A Study Protocol. Springerplus, 4, 709. https://doi.org/10.1186/s40064-015-1490-9

[73] WHO (2012) Middle East Respiratory Syndrome Coronavirus (MERS-CoV): MERS-CoV in Republic Korea at a Glance. http://www.wpro.who.int/outbreaks_emergencies/wpro_coronavirus/en

[74] Hung, I.F., To, K.K., Lee, C.K., et al. (2011) Convalescent Plasma Treatment Reduced Mortality in Patients with Severe Pandemic Influenza A (H1N1) 2009 Virus Infection. Clinical Infectious Diseases, 52, 447-456. https://doi.org/10.1093/cid/ciq106

[75] Hung, I.F.N., To, K.K.W., Lee, C.K., et al. (2013) Hyperimmune IV Immunoglobulin Treatment: A Multicenter Double-Blind Randomized Controlled Trial for Patients with Severe 2009 Influenza A(H1N1) Infection. Chest, 144, 464-473. https://doi.org/10.1378/chest.12-2907

[76] Mo, Y. and Fisher, D. (2016) A Review of Treatment Modalities for Middle East Respiratory Syndrome. Journal of Antimicrobial Chemotherapy, 71, 3340-3350. https://doi.org/10.1093/jac/dkw338

[77] Marano, G. Vaglio, S., Pupella, S., et al. (2016) Convalescent Plasma: New Evidence for an Old Therapeutic Tool? Blood Transfusion, 14, 152-157.

[78] Yang, X.M. and Hou, J.F. (2020) The Current Status of Convalescent Plasma's Application in Acute Viral Infectious Diseases and Its Prospects in the Treatment of New Coronavirus Pneumonia. Chinese Journal of Biologicals, 1-5.

[79] Cunningham, A.C., Goh, H.P. and Koh, D. (2020) Treatment of COVID-19: Old Tricks for New Challenges. Critical Care, 24, 91. https://doi.org/10.1186/s13054-020-2818-6 
[80] Amoss, H.L. and Chesney, A.M. (1917) A Report on the Serum Treatment of Twenty-Six Cases of Epidemic Poliomyelitis. Journal of Experimental Medicine, 25, 581-608. https://doi.org/10.1084/jem.25.4.581

[81] Luke, T.C., Kilbane, E.M., Jackson, J.L. and Hoffman, S.L. (2006) Meta-Analysis: Convalescent Blood Products for Spanish Influenza Pneumonia: A Future H5N1 treatment? Annals of Internal Medicine, 145, 599-609. https://doi.org/10.7326/0003-4819-145-8-200610170-00139

[82] Mcguire, L.W. and Redden, W.R. (1918) The Use of Convalescent Human Serum in Influenza Pneumonia: A Preliminary Report. American Journal of Public Health, 8, 741-744. http://www.pubmedcentral.nih.gov/articlerender.fcgi?artid=1362336 https://doi.org/10.1001/jama.1918.26020420013013e

[83] WHO (2013) WHO-International Severe Acute Respiratory and Emerging Infection Consortium (ISARIC) MERS-CoV Outbreak Readiness Workshop.

http://www.who.int/csr/disease/coronavirus_infections/MERS_outbreak_readiness_ workshop.pdf 